\title{
WILDSCAPES, DUDESCAPES, AND THE DUDE RANCHING Aesthetic: Grand Teton National Park 1908-1940
}

\author{
AMANDA REES $\uparrow$ GEOGRAPHY \& RECREATION \\ UNIVERSITY OF WYOMING $\uparrow$ LARAMIE
}

\section{$\downarrow$ INTRODUCTION}

"Dude Ranch" is not an expression that carries a clear-cut meaning to everyone, for a dude ranch is neither a summer hotel nor a farm where dudes "ranch". ... The most typical dude ranches of all the West are in this section of Wyoming. They range all the way from the most exclusive outfits that require references and advance reservations for not les than three weeks or a month at around $\$ 70$ per week per person-including saddle horse and equipment, modern cabin, meals and other advantages - to the guest ranches or outfitters where accommodation may be had by the day, week or season. The person of moderate means can arrange his vacation in Jackson Hole to fit his purse. (Jackson Hole: Where to Go and What To See, published between 1929-1950)

The American West is home to one of the most distinctive agricultural tourism activities in the world: dude ranching (Rees 2004). Dude ranching is the "single most unique contribution of the Rocky Mountain West to the ever-growing national vacation industry" (Roundy 1973), and it has been crucial in shaping the ways in which the West is perceived, working to effect continuing romantic notions of the American West (Rodnitzky, 1968). Though dude ranches can be found in the East (Zimmerman 1998), the South, the Southwest, California, Hawaii, and the Northwest, it is the Northern Rocky Mountain region, especially Montana and Wyoming, which forms the nucleus of dude ranch tourism (Rees 2005). However, unlike cattle ranching, agriculture, and mineral extraction, tourism has rarely received the attention it deserves in Wyoming, though it continues to be an important part of the Western image, as well as an important factor in the production and reproduction of that image. Just as dude ranching has failed to receive the attention it deserves in the state, it has also failed to receive that attention in one of the region's densest nexus or collection of dude ranching, Jackson Hole, and in particular, Grand Teton National Park (GTNP). Indeed, dude ranches have faired miserably in the first seventy-five years of the park's existence. As cultural landscapes dude ranches have been deemphasized in favor of celebrating the natural environment. This project's research has revealed that a vast majority of the thirty-three dude ranches that once functioned in what is now GTNP have disappeared, been auctioned off, burned, pulled down, or allowed to rot in situ. In the last decade, critics of federal cultural resource management philosophy sought to reject this often-fragmented approach to cultural heritage protection, and looked to embrace environmental and cultural resources as an indivisible whole (Hufford 1994) and this research project falls within that effort to produce a narrative that embraces both environmental and cultural resources to tell a story of the ways in which humans and nature have interacted through tourism in GTNP.

\section{$\uparrow$ METHODOLOGY}

1. Documents associated with individual dude ranches and dude ranch tourism at the American Heritage Center archives including the Dude Ranch Association collection located at the American Heritage Center and the Grace Hebard Collection at the University of Wyoming were identification, collected, and analyzed. In addition, archival records at Grand Teton National Park were utilized, along with various 
memoirs, interviews, and archival records at the Jackson Hole Historical Society. These documents were deployed to locate the dude ranch sites, to provide historical images, and other relevant documents for interpreting individual ranches, the Dude Ranch Association, and other organizations involved in regional tourism.

2. Field visits were made to almost all the sites (work is still continuing to identify the last few dude ranch locations). The location of each ranch site was registered using Global Positioning System technology. Photographic images representing the built environment at the sites were made. Notes were made of the arrangement of each ranch as well as the viewshed of each ranch.

3. Dude ranch biographies were established for each of the ranches where data permitted.

4. Dude ranches were characterized according to particular criteria of operation.

\section{RESEARCH FINDINGS}

1. Definitions of Dude Ranching and Dude

2. Number and Periodization of Dude Ranch Operations

3. Characterization of Dude Ranch Operations

4. Location of Dude Ranch Sites

5. Aesthetics of the Dudescape

6. Class and Dude Ranching

\section{Definitions of Dude Ranching and Dude}

As the quotation at the beginning of this report suggests, the term dude ranch is slippery. A literature review was made of the dude ranch texts to establish a national definition then regional and local definitions of the terms dude ranching and dude were developed to establish a working definition of the term.

\section{Number and Periodization of Dude Ranch Operations}

Prior to this study, dude ranching in Grand Teton National Park had primarily received attention from Park Historian John Daugherty (1999) who had identified seventeen dude ranch operations in the Park beginning in 1907-8. By examining archival records, especially maps and memoirs, the number of dude ranches expanded to thirty-three. Daugherty (1999) constructed three eras into which the dude ranches fell "Pioneer, Golden Age, and Depression." As the number of dude ranches increased, the research revealed three additional eras to add to Daugherty's work.
1. Progenitor Era: 1880-1908

Earliest touristic operations found primarily on the major route from Yellowstone National Park and Jackson around Jackson Lake area.

2. Pioneer Era: 1908-1919 Establishment of the three grand dames of dude ranching in Jackson Hole

3. Golden Age Era: 1920-1929 Rapid expansion and growth in dude ranching in the southern part of the Park.

4. Depression Era 1930-1945

Massive reduction in NUMBERS of operations established, and purchase of many dude ranches by the Snake River Land Company.

5. Post War Era: 1945-1980

Slow devolution of dude ranching operations in response to the lifetime lease arrangements with Grand Teton National Park.

6. Vestige Era: 1990-2005

Two functioning dude ranches remain within Park boundaries.

As Lawrence Bourn has argued "Dude ranching did not begin at a specific time and then simply grow into a large industry. It developed slowly from several divergent sources in different locales and varying circumstances and then gradually assumed a definite and identifiable form" (Borne 1983). Thus was the case in the valley of the Grand Tetons, and the progenitor era nods to that slow development. In relation to the progenitor era there is evidence to suggest that organizations offered some characteristics of dude ranching operations within a touristic framework prior to $1907-8$.

Though Daugherty's eras ended with the Depression, there has been a sixty-year history of dude ranching in the Park since that point. The post World War Two era reveals a period of slow devolution in the Park's dude ranch industry. As dude ranch operators aged, they could not sell their businesses as the vast majority had sold their property and had established a life-time lease agreement with the Snake River Land Company. Organized by John D. Rockefeller Jr., the Snake River Land Company acquired dude ranch properties to gift to the federal government in order to expand the Park from its original 1929 size to its contemporary size. When Rockefeller gave the purchased land to the National Park Service the NPS held the leases until the deaths of the dude ranchers and the land reverted back to the Park. Since 1990 the dude ranch business has stabilized at its low point with only 
two functioning dude ranches in the Park: the Triangle $X$, operated as a concession in the park, and Moosehead, a private-owned in-holding completely within the Park boundaries.

\section{Characterization of Dude Ranch Operations}

In addition to the six eras of dude ranching in the Park, there are five major modes of dude ranching:

1. Progenitor operations that offered some aspects of dude ranching with hunting/fishing season services as well as summer season services with reasonably appointed accommodations (log or canvas cabins) and additional services

2. Grand dame dude ranches established by and for an eastern elite clientele

3. Invitation-only dude ranches where paying guests were invited to stay

4. Juvenile dude ranches created for high school aged boys and girls

5. Guest ranches offering more modest operations still offering dude accommodations

\section{Location of Dude Ranch Sites}

Each site that could be located with the above research methods was visited and a log of its absolute location using a Global Positioning System unit (GPS) was made. A map of the dude ranch nexus was created.

\section{Analysis of the Landscape Aesthetic}

The landscape aesthetic analysis is divided into two sections: the arrangement of the dude ranch built space, and the viewshed utilized by each dude ranch.

When considering dude ranch aesthetics there is a rich and subtle blend of architecture, what the National Park Service characterizes a dude ranch vernacular style. This style has been characterized as being developed as part of an earlier "agricultural complex or were built to echo-in materials, design, and placement-buildings of the pioneer/homestead era" (US Department of Interior 1997). Dude ranches, auto courts, and other tourist facilities:

reflected the deliberate attempt (culturally rather than environmentally imposed) to create a "Western style" attractive to eastern guests. . . In Grand Teton this led to the construction of log buildings conscientiously made to look like pioneer structures, long after the economic and environmental rationale for this vernacular style had waned. . . As dude rancher Arthur Carhart informed prospective guests in Hi Stranger!: "The main lodge of a highly developed dude ranch is the outgrowth of the owner's 'big house' . . but they are a long way advanced over their counterparts of yesterday - and you'll be glad of that (Carhart, 1949, US Department of Interior 1997).

However, this research focused less on the style of built space and more on its arrangement. Out of thirty-three dude ranches only twelve outfits provided enough material culture, archival records, or personal memories from former dudes and dude ranch employees, for analysis.

a. Relationship Between Main Lodge and Cabins: The arrangement of the dude ranch built space in particular the relationship between the main lodge to the small residential cabins revealed four major patterns: 1) a hen and chicks pattern where the cabins clustered behind the lodge, 2) a horseshoe pattern, where the lodge formed one end of a horseshoe and the cabins were arranged in an elongated half circle from that point, 3) a pattern that followed the watercourse and built space was boarded by buildings on one bank, and 4) a pattern centered on the road, where the dude ranch lodge and other structures faced and were organized along the road, offering community services such as a post office or school. Some dude ranches deploy more than one pattern.

b. Relationship Between Built Space and the Viewshed. Though this was one of the densest ranch mountain resort communities in the American West, dude ranches in the Grand Tetons did not always choose a viewshed that focused on the Teton Range. Viewsheds can be characterized as: 1) the Grand Tetons, 2) the Jackson Valley, 3) a water focus, in particular the Snake River, and d. the road.

\section{Class and Dude Ranching}

In addition to the characterization, location, and aesthetics of dude ranching, one of the most powerful themes arising from this dude ranch research was the relationship of class and dude ranching. In the first half of the twentieth century, individual dude ranches, the Wyoming Dude Ranch Association, the railroads and airlines and even the State of Wyoming's support for dude ranch tourism revealed that class shaped the dude ranch experience. This aspect of the analysis is well underway and a manuscript has already been accepted for publication. 


\section{OTHER RESEARCH OUTCOMES}

Article

"A Classless Society:" Dude Ranching in the Tetons 1908-1955" Annals of Wyoming accepted for publication fall, 2005

Conference Paper

"Class and the Dudescape: Dude Ranching in Grand Teton National Park 1908-1955" American Association of Geographers, Denver, April 2005

Invited Presentations

口 "A History of Dude Ranching in Wyoming". Wyoming Dude Ranch Association Annual Meeting, Casper, Wyoming, April 2005

口 "How to Become a Dude or Dudeen: Dude Ranching in Grand Teton National Park 1890-1955" Albany County Historical Society, April 2005

口 "Dude Ranching in Wyoming" Rangeland Economics Class, University of Wyoming, April 2005

口 "Dude Ranching and Dudes of the Social Elite" Geography Spring Speaker Series, University of Wyoming, April 2005

口 "Where Have all the Dude Ranches Gone: Grand Teton's Tourist Landscapes." University of Wyoming-National Park Service Research Station, AMK Ranch, Jackson, Wyoming, June 2005

口 "Dude Ranching Aesthetics." Dubois Community Library, June 2005

Class Materials

a Developed dude ranch materials for G\&R 4420 Tourism and Recreation, Spring 2005

- Directed undergraduate research project

口 "Dude Ranching and Ecotourism: A Critical Analysis" Spring 2005

\section{PROJECTS IN PREPARATION}

\section{Book Manuscripts}

口 "Jackson Hole Dude Ranching" in collaboration with the Jackson Hole Historical Society (in negotiation)

口 "My Kind Of Dude Ranching" in collaboration with the Center for American Places.
"Park Dudes and City Dudes" in development

\section{Museum Exhibition}

口 Happy Trails: Dude Ranch Elites and Grand Teton National Park 1908-1940 Photographic exhibition for possible collaboration with the American Heritage Center, University of Wyoming and Jackson Hole Historical Society.

\section{NEXT DIRECTIONS FOR RESEARCH}

1. Extend research beyond dude ranching to incorporate other touristic activities in GTNP to reveal the extent of tourism in the Park, the relative importance of dude ranching in that larger tourism context.

2. Determine the economic impacts of dude ranching in the Jackson Valley.

3. Extend research into the relationship between dude ranching and the analytical category of class.

4. Begin research to explore the dude perspective through personal accounts, photographs and letters.

5. Examine the role of women in dude ranching: both as dude ranchers and dudettes.

6. Investigate the conflict and symbiosis between the development of Grand Teton National Park as a "museum on the hoof" and the town of Jackson as a "frontier town."

7. Explore NPS regional archives to gain further detail of each dude ranch site.

\section{ACKNOWLEDGEMENT}

Thanks to Hank Harlow for being an enthusiastic advocate of this project, to Pam Holtman, GTNP Historian, who gave me invaluable information and support. Thanks to historians Phil Roberts for his unrelenting enthusiasm for this project and Bob Righter for his excellent ideas and encouragement. Finally thanks goes to Mary McKinney for her untiring and enthusiastic work in historic preservation and the telling of cultural resources stories about and within Grand Teton National Park. 


\section{$\downarrow$ Literature Cited}

Bourne, Lawrence R. Dude Ranching: A Complete History Albuquerque: University of New Mexico Press, 1983.

Carhart, Arthur Hi, Stranger! The Complete Guide to Dude Ranches Chicago, Ziff-Davis, 1949.

Daugherty, John A Place Called Jackson Hole: A Historic Resource Study of Grand Teton National Park, Moose, Grand Teton Natural History Association, 1999.

Hufford, Mary (ed.) Conserving Culture: A New Discourse on Heritage Urbana: University of Illinois Press, 1994

Jackson Hole: Where to Go ... What to See published by Harry C. Duntsch Riverton, Wyoming, no date published between 1929 and 1950, 18-19.

Rees, Amanda "Be Our Guest: Wyoming Dude Ranching" Phil Roberts (Ed.) Readings in Wyoming History: Issues in the History of the Equality State Laramie: Skyline West Pres, 2004.
Rees, Amanda “A Classless Society:" Dude Ranching in the Tetons 1908-1955" Annals of Wyoming (forthcoming fall 2005)

Rodnitzky, Jerome L. "Recapturing the West: The Dude Ranch in American Life." Arizona and the West 1968, Vol 10 11-126.

Roundy, Charles G. "The Origins and Early Development of Dude Ranching in Wyoming." Annals of Wyoming Vol 45, 1973: 5-25.

United States Department of Interior National Park Service, National Register of Historic Places, Grand Teton National Park Multiple Property Submission, November $20^{\text {th }}, 1997,70$.

Zimmerman, Emily "Eastward Ho: The Dude Ranch Hits the Trail 1925-55" web site http://xroads.virginia.edu/ MA98/zimmerman/d uderanch/home.html, 1998 American Studies Program, University of Virginia accessed May 13, 2005. 